\title{
Author Correction: Infectious DNAs derived from insect- specific flavivirus genomes enable identification of pre- and post-entry host restrictions in vertebrate cells
}

\author{
Thisun B. H. Piyasena (D), Yin X. Setoh, Jody Hobson-Peters, Natalee D. Newton, \\ Helle Bielefeldt-Ohmann, Breeanna J. McLean, Laura J. Vet, Alexander A. Khromykh \& \\ Roy A. Hall
}

Correction to: Scientific Reports https://doi.org/10.1038/s41598-017-03120-1, published online 07 June 2017

In this Article, the legend of Figure 4 is incorrect:

"Viral replication analyses in WT and IFNAR ${ }^{-1-}$ MEF cells. (a) Cells infected at an MOI of 1 or transfected CPEC constructs of either $\mathrm{WNV}_{\mathrm{KUN}}$ or PaRV with a CMV promoter. (b) Cells transfected with genomic RNA of either PaRV, $\mathrm{WNV}_{\mathrm{KUN}}$, PCV, PCV/WNV $\mathrm{KUN}_{\text {- }}$ prME or $\mathrm{WNV}_{\mathrm{KUN}} / \mathrm{PCV}$-prME. Monolayers were fixed $72 \mathrm{hrs}$ post-infection. IFA analysis was performed by probing with anti-PaRV (7D11) and anti-WNV E (3.91D) mouse monoclonal antibodies. The nucleus of each cell was stained with Hoechst 33342 . Images were taken at $\times 40$ magnification".

should read:

"Viral replication analyses in WT and IFNAR ${ }^{-1-}$ MEF cells. (a) Cells infected at an MOI of 1 with either WT $\mathrm{WNV}_{\mathrm{KUN}}$ or WT PaRV. (b) Cells transfected with CPEC constructs of either $\mathrm{WNV}_{\mathrm{KUN}}$ or PaRV with a CMV promoter. Monolayers were fixed $72 \mathrm{hrs}$ post-infection. IFA analysis was performed by probing with anti-PaRV (7D11) or anti-WNV E (3.91D) mouse monoclonal antibodies. The nucleus of each cell was stained with Hoechst 33342. Images were taken at $\times 40$ magnification".

(i) Open Access This article is licensed under a Creative Commons Attribution 4.0 International License, which permits use, sharing, adaptation, distribution and reproduction in any medium or format, as long as you give appropriate credit to the original author(s) and the source, provide a link to the Creative Commons license, and indicate if changes were made. The images or other third party material in this article are included in the article's Creative Commons license, unless indicated otherwise in a credit line to the material. If material is not included in the article's Creative Commons license and your intended use is not permitted by statutory regulation or exceeds the permitted use, you will need to obtain permission directly from the copyright holder. To view a copy of this license, visit http://creativecommons.org/licenses/by/4.0/.

(C) The Author(s) 2019

Australian Infectious Diseases Research Centre, School of Chemistry and Molecular Biosciences, The University of Queensland, St Lucia, 4072, Queensland, Australia. Thisun B. H. Piyasena, Yin X. Setoh and Jody Hobson-Peters contributed equally. Correspondence and requests for materials should be addressed to A.A.K. (email: alexander. khromykh@uq.edu.au) or R.A.H. (email: roy.hall@uq.edu.au) 